\title{
Phonemes in muna language
}

\author{
La Ode Nggawu \\ Halu Oleo University Kendari, Indonesia
}

\begin{abstract}
Muna language as other languages has certain phonemens. It is one of the aspects causing one language differs to others. The aim of the study is to explore the phonemes in Muna, a language which is used in Muna Regency, Southeast Sulawesi, Indonesia. The data was collected through participant speaking and scrutinize methods with recording and noting techniques, and analyzed using apportioned methods. The presentation of data was done inductively from data, description, and taking conclusion. Muna language has 5 (five) vowels, namely/i, a, e, o, u/. These vowels can be realized in long sounds, such as [i:], [a:], [e:], [o:], and [u:]. Besides, Muna language has 15 dipthongs, namely /ai/, /au/, /ae/, /ao/, /ia/, /iu/, /ie/, /io/, /ea/, /eu/, /eo/, /oa/, /oe/, /ou/, and /oi/. Related to consonant, Munalanguage has 19 consonants, namely /b/,/b/,/p/, $/ \mathrm{d} /, / \mathrm{b} /, / \mathrm{t} /, / \mathrm{g} /, / \mathrm{g} /, / \mathrm{k} /, / \mathrm{m} /, / \mathrm{n} /, / \mathrm{n} /, / \mathrm{f} /, / \mathrm{s} /, / \mathrm{h} /, / 1 /, / \mathrm{r} /, / \mathrm{w} /$, and $/ \mathrm{y} /$, and clusters/ns/, $/ \mathrm{nt} /, / \mathrm{nd} /, / \mathrm{mb} / / \mathrm{nk} /, / \mathrm{ng} /$, and $/ \mathrm{mp} /$. Besides, there is not any consonant that place the final position, which is called as vocalist language.
\end{abstract}

Keywords - phonomes, vowel, consonant, cluster

\section{Introduction}

Language functions as a tool to know the changing and giving description of activity in the past. Muna language as one of local languages in Southeast Sulawesi is an interesting object for the researchers since it is very unique, mainly in terms of the phonemes.Muna languageisusedorspokenmainly in Muna Regency (standarddialect) and Buton Island in thenorth, Gu, Lakudo,andMawasangkaDistricts(southdialect).

The basic unit of language is phoneme. Phoneme is a part of the study of language sounds [1]: [2]. Besides, air current, articulators, and articulation point are the aspects that influence creating language sound or phoneme. In general, there are two kinds of phonemes, namely segmental phoneme (vowel and consonants) and suprasegmental phonemes (stress, tone, long, and intonation). Stress phonemes can be symbolized with ['] in the right above of it and long sound phoneme can be symbolized with [:] in the right of it, and it often found on vowels.

The phoneme which is created when the air current does not has articulation in the sound cannal is called as vowel [1]. It consists of mouth or oral cavity. Vowelphonemecanbegrouped in lowandhighofthetongue, tonguemove, glottiscondition, andlipform [3]. While, the phonemes which is created when there is articulation of air current is called as consonants. When there is vibration on vocal cords on the process of articulation, it is called as voiced consonants, and when it does not create vibration on vocal cords, it is called as voiceless consonants [4]. 
Further, consonant phonemescan be classified into: (a) manner of articulation, (b) place of articulation, (c) the relationship between active and passive articulators, and (d) vibrate or not of vocal cords. In addition, language also has semi-vowel phonemes such as $/ \mathrm{w} /$ as bilabial and $/ y /$ as medial palatal sounds. It has consonant sounds, but it does not create the completed or pure consonant in the articulation [3].

Phonemes is studied in phonology or phonetics. Phonetics can be divided intoacousticphonetics, auditory phonetics, and articulator phonetics.Acoustic phonetics studies the features of sounds or phonemes, or as interdisciplinary science of linguitics and physisc. Auditory phonetics studies how the ear catch or listen the spoken languages, or as interdisciplinary science of linguitics and medical. Articulatory phonetics studies how the vocal tracts or vocal apparatus create the sound of language. From those categories, the focus of this study is articulatory phonetics.

The vowels which is categorized based on low and high of the tongue are as follow:

High vowel : [i], [I], [u], and [U]

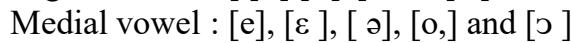

Low vowel : [a]

The vowels which is categorized based on tongue move are as follow:

Front vowel : [i], [I], [e], [c], and [a]

Centre vowel : [ə]

Back vowel : [u], [U], [o], and [0]

The vowels which is categorized based on glottis condition are as follow:

Closed vowel : : [i] and [u]

Semi-closed vowel : : [e] and [o]

Open vowel : : $:[\varepsilon]$ and $[0]$

Semi-open vowel : : [a]

The vowels which is categorized based on lip form condition are as follow:

Unrounded vowel : $[\mathrm{i}],[\mathrm{I}],[\mathrm{e}],[\varepsilon],[\mathrm{\partial}]$, and [a]

Rounded vowel : $[\mathrm{u}],[\mathrm{U}],[\mathrm{o}]$, and [ว].

Basically, there are several previous studies which are relevant to this study. Taembo [5] studied about a comparative study between Muna and Wakatobi languages (synchronic and diachronic analysis). It also described in a brief of phonemes in Muna language. Yatim [6] in his study entitled "Bahasa Muna" also discussed about phonemes but without giving evidences of phonemes. Likewise, Berg [7] gave more description of a grammar in Muna language. Berg did not discussed particularly long vowel sounds as variations of vowel phonemes. Fatimah [8] studied about maintenance of Muna language, but her study did not explain the phonemes in Muna langauge. Fernandez, et.al. [9] investigated the language family relationship among Muna, Buton, and Wakatobi in Southeast Sulawesi based on linguistics history comparison and ethnolinguistics. Their study also described the phonemes in Muna language, but it has just a brief description of phonemes.

Based on the explanation and previous studies above, it has not been found particularly study of phonemes in Muna language. This study differs to previous studies because it also discussed variation of vowel such long and short vowel sounds and the gildes which are not found in the previous studies. Therefore, this study investigated the phonemes in Muna language. It includes vowel phenemes with its variations, glide, and consonant phonemes with its cluster. 


\section{Methods}

This study used qualitative descriptive method. The sources of data are from informants as native speakers of Muna language. The data was collected through participant speaking and scrutinize methods [10]; [11]. Besides, it used recording and noting techniques. The data was analyzed decriptive qualitatively through apportioned methods [10]. The described data was grouped in vowel and consonant phonemes. Each phoneme firstly was described and analyzed alone based on data, and then related to other phonemes as the conclusion of phonemes in Muna language. The data was presented inductively from data, analysis, and taking conclusion.

\section{Result and Discussion}

\subsection{Vowel}

Basedonthe data found in thefield, Muna language has vowelphonemes/i/, /u/, /e/, /o/, and /a/. They are proved by minimal pairs technique as follow:

$\begin{array}{lll}\text { Vowel /i/ and /u/: } & \text { /ise/ 'satu' } & \text { /use/ 'hujan' } \\ \text { Vowel /a/ and /u/: } & \text { /tola/ 'panggil } & \text { /tolu/ 'tiga' } \\ \text { Vowel /e/ and /u/: } & \text { /ane/ 'kalau' } & \text { /anu/ 'jenis panggilan' } \\ \text { Vowel /a/ and /e/: } & \text { /lani / 'langit' } & \text { /leni/ 'berenang' } \\ \text { Vowel /o/ and /i/: } & \text { /kori/ 'lepra' } & \text { /kiri/ 'kikis' }\end{array}$

All vowels in Muna language can be put in initial, medial, or final position. It means that it is categorized as vocalist language. Further, vowel/i/ can be realized in long sound such as in the words of mi:na'not' and pi: 'very pain'. Long sound of /i/ which is written in [i:] is not phonemic but also as phoneticssoundonly. Vowel/u/ can be realized in long sound such as in the words of $\boldsymbol{u}: m b e$ 'yes'and tu: 'knee'. Long sound of $/ \mathrm{u} / \mathrm{which}$ is written in [u:] is not phonemic but also as phonetics sound only. Likewise, vowel /e/ can be realized in long sound such as in the words of kade:de 'difficult' and ne: 'nose'. Long sound of /e/ which is written in [e:] is not phonemic but also as phonetics sound only.Vowel/o/ also can be realized in long sound such as in the words of mo:ho 'hot', kanso:pa 'west'. Long sound of /o/ which is written in [o:] is not phonemic but also as phonetics sound only. Last, vowel /a/ also can be realized in long sound such as in the words of pa: 'armpit', la:'river'. Long sound of /a/ which is written in [a:] is not phonemic but also as phonetics sound only. In communication, the short and long sounds do not influence the understanding of both speaker and addresse. They can understand each other. It seems as regional dialect. Therefore, the long sounds are not phoneme, but as variations of phonemes (phonetic).

In addition, Muna language has vowel sequences, which create glides of $\left.{ }^{\mathrm{y}}\right]$ and $\left.{ }^{\mathrm{w}}\right]$. The glideof['] can be found in vowel sequences as follow: /ua/, /au/, /ao/, /eu/, /oi/, /oa/, and /ou/, while glide of $\left.{ }^{\mathrm{y}}\right]$ found in vowel sequences as follow: ai/, /ae/, /ia/, /iu/, /ie/, /io/, /ea, /eo/, /oe/, and /oi/. The glide of $\left.{ }^{[}{ }^{\mathrm{w}}\right]$ can be found in the following examples:

$\begin{array}{llll}\text { 1. } / \mathrm{ua} /: & / \text { suana/ } & {\left[\mathrm{su}^{\mathrm{w}} \mathrm{ana}\right]} & \text { 'right' } \\ \text { 2. } / \mathrm{au} /: & / \mathrm{gau} / & {\left[\mathrm{ga}^{\mathrm{w}} \mathrm{u}\right]} & \text { 'cook' } \\ \text { 3. } / \mathrm{ou} /: & / \mathrm{rou} / & {\left[\mathrm{ro}^{\mathrm{w}} \mathrm{u}\right]} & \text { 'drink' } \\ \text { 4. } / \mathrm{eu} /: & / \text { nofeu/ } & {\left[\text { nofe }^{\mathrm{w}} \mathrm{u}\right]} & \text { 'blow' } \\ 5 . \quad / \mathrm{ao} /: & \text { /pandehao/ } & {\left[\text { pandeha }^{\mathrm{w}} \mathrm{o}\right]} & \text { 'konw' }\end{array}$


6. /ou/: /bughou/ [bog $\left.\mathrm{g}^{\mathrm{w}} \mathrm{u}\right]$ 'new'

7. /au/: /fokoinau/ [fokoina $\left.{ }^{\mathrm{w}} \mathrm{u}\right]$ 'aunt'

8. /oa/: /anoa/ [anowa] 'she/he'

The glide of $\left.{ }^{\mathrm{y}}\right]$ can be found in the following examples:

\begin{tabular}{|c|c|c|c|}
\hline 1. /ai/: & /ai/ & {$\left[\mathrm{a}^{\mathrm{y}_{\mathrm{i}}}\right]$} & 'young brother/sister' \\
\hline 2. /ea/: & /wea/ & {$\left[\mathrm{we}^{\mathrm{y}} \mathrm{a}\right]$} & 'shoulder' \\
\hline 3. /ae/: & /nĝae/ & {$\left[\mathrm{ga}^{\mathrm{y}} \mathrm{e}\right]$} & 'cry' \\
\hline 4. /oe/: & /noere/ & {$\left[\right.$ no $^{\mathrm{y}}$ ere $]$} & 'stand' \\
\hline 5. /ia/ : & /ĝgohia/ & [gohi $\left.{ }^{\mathrm{y}} \mathrm{a}\right]$ & 'salt' \\
\hline 6. /iu/ & /baliu/ & [bali $\left.{ }^{\mathrm{y}} \mathrm{u}\right]$ & 'buy' \\
\hline 7. /ie/ : & /baribarie/ & [6aribari $\left.{ }^{\mathrm{y}} \mathrm{e}\right]$ & 'all' \\
\hline 8. /io/ : & /nefio/ & {$\left[\right.$ nefi $\left.^{y_{0}}\right]$} & 'press' \\
\hline 9. /eo/: & /oleo/ & /ole $\left.{ }^{\mathrm{y}} \mathrm{o}\right]$ & 'day’ \\
\hline 10. /ea/ : & /rea/ & {$\left[\mathrm{re}^{\mathrm{y}} \mathrm{a}\right]$} & 'blood' \\
\hline 11. /oi/: & /fokoinau/ & [foko ${ }^{\mathrm{y}}$ inau] & 'aunt' \\
\hline 12. /eu/: & /deu/ & {$\left[\mathrm{de}^{\mathrm{y}} \mathrm{u}\right]$} & 'pin' \\
\hline
\end{tabular}

Based on the examples above, Muna language has several vowel sequences. They are /ua/, /au/, /ou/, /eu/, /ao/, /ou/, /oa/, /ai/, /ea/, /ae/, /oe/, /ia/, /ie/, /io/, /eo/, /oi/, and /eu/.

\subsection{Consonants}

Muna language has 19 consonants, /b/, /b/, /p/, /d/, /d /, /t/, /g/, /g/g/, /k/, /m/, /n/, /g/, /f/, /s/, $/ \mathrm{h} /, / \mathrm{l} /, / \mathrm{r} /, / \mathrm{w} /$, and $/ \mathrm{y} /$. As vowel, the consonants of Muna also proved by minimal pairs as follow.
1) $/ \mathrm{b} /-/ \mathrm{b} / \quad$ : /baru/ 'happy'
2) $/ \mathrm{f} /-\mathrm{p} / \mathrm{i} \quad$ : findo/ 'bananaleaves'
3) $/ \mathrm{d} /-/ \mathrm{d} / \quad:$ : $/$ dolo/ 'snout'
4) $/ \mathrm{t} / \mathrm{-} / \mathrm{l} / \mathrm{:} / \mathrm{otu} / \mathrm{H}$ 'louse'
5) $/ \mathrm{g} / / \mathrm{g} / \quad:$ /gila/ 'crazy'
6) $/ \mathrm{k} /-\mathrm{h} / \mathrm{:} / \mathrm{kala} /$ 'walk'
7) $/ \mathrm{m} / \mathrm{-} / \mathrm{w} / \quad: \quad \mathrm{manu} /$ 'chicken'
8) $/ \mathrm{n} / \mathrm{-} / \mathrm{t} /: /$ nara/ 'bored'
9) $/ \mathrm{r} / \mathrm{/n} / \mathrm{n} / \mathrm{rea} / \quad$ 'blood'
10) $/ \mathrm{r} / \mathrm{/} / \mathrm{s} / \quad$ : $/$ ria/ 'noisy'
11) $/ \mathrm{y} /-\mathrm{lo} / \quad$ : /topka/ 'vomit'
12) $/ \mathrm{f} / / \mathrm{h} / \mathrm{\quad} \quad: / \mathrm{ifi} / \quad$ 'fire'
13) $/ 1 /-/ p / \quad$ : /lani/ 'sky'
14) $/ \mathrm{h} / / \mathrm{g} / \mathrm{g} \quad$ : /horo/ 'fly'
15) $/ y /-/ \varnothing / \quad:$ /yaro/ 'noble'
/baru/ 'fertilizer'
/pindo/ 'repaired'
/dolo/ 'cam'
/olu/ 'cloud'
/ĝila/ 'mole'
/hala/ 'false'
/wanu/ 'wake up'
/gara/ 'oh I see'
'oh I see'
/nea/ 'name'
/sia/ 'beat'
/toka/ 'finish'
/ihi/ 'meat'
/pani/ 'wing'
/ĝoro/ 'throw'

The distribution of consonant phonemes are only in the initial and medial position. There is not any consonant in final position. It means that Muna is vocalist language. Further, Muna has several cluster, namely $/ \mathrm{ns} /, / \mathrm{nt} /, / \mathrm{nd} /, / \mathrm{mb} /, / \mathrm{nk} /, / \mathrm{ng} /$, and $/ \mathrm{mp} /$ as in the words of /andoa/ 'they', /insaidi/ 'we', /kantiba' 'right', /noambano/ 'shy', /tonka/ 'vomit', /bangai/ 'kind of vegetable', and /tampe/ 'much'. In addition, phonemes of $/ \mathrm{c} /, \mathrm{j} /, / \mathrm{x} /, / \mathrm{z} /, / \mathrm{v} /$, and $/ \tilde{\eta} /$ are not found in Muna language. 


\section{Conclusion}

Muna language has 5 vowels, namely $/ \mathrm{i} /, / \mathrm{a} /, / \mathrm{e} /, / \mathrm{o} /$, and $/ \mathrm{u} /$. These vowels can be realized in long sounds, such as [i:], [a:], [e:], [o:], and [u:]. Besides, Muna language has dipthongs/ua/, /au/, /ao/, /eu/, /oi/, /oa/, /ou/, ai/, /ae/, /ia/, /iu/, /ie/, /io/, /ea, /eo/, /oe/, and /oi/. Related to consonant, Muna language has 19 consonants, namely /b/, /b/, /p/, /d/, /d/, /t/, /g/, /g/g/, /k/, /m/, $/ \mathrm{n} /, / \mathrm{n} /, / \mathrm{f} /, / \mathrm{s} /, / \mathrm{h} /, / \mathrm{l} /, / \mathrm{r} /, / \mathrm{w} /$, and $/ \mathrm{y} /$, and clusters $/ \mathrm{ns} /, / \mathrm{nt} /, / \mathrm{nd} /, / \mathrm{mb} / / \mathrm{nk} /, / \mathrm{\eta g} /$, and $/ \mathrm{mp} /$. There is not any consonant that place the final position. It means that Muna is categorized as vocalist language.

\section{References}

[1] H. Lapoliwa, "A Generative Approach to the Phonology of Bahasa Indonesia," Camberra, 1981.

[2] I. D. P. Wijana, Kartun: Studi Tentang Permainan Bahasa. Yogyakarta: Ombak, 2004.

[3] Marsono, Fonetik. Yogyakarta: Gadjah Mada University Press, 2008.

[4] Samsuri, Analisi Bahasa: Memahami Bahasa Secarallmiah. Malang: Penerbit Erlangga, 1991.

[5] M. Taemb, "A Comparative Study between Muna and Wakatobi Languages (Synchronic and Diachronic Analysis," in Prosiding in Seminar Nasional Bahasa Ibu VIII, 2015.

[6] N. Yatim, Bahasa Muna. Jakarta: Pusat Pengembangan dan Pembinaan Bahasa, Departemen Pendidikan dan Kebudayaan, 1981.

[7] R. Van Den Berg, A Grammar of the Muna Language. The Netherlands: Foris Publications Hollands, 1989.

[8] S. Fatimah, "Pemertahanan Bahasa Muna di Daerah Rantau Sulawesi Selatan," in Prosidings of International Congress of Local Languages of Southeast Sulawesi. Language Office of Southeast Sulawesi, National Education Ministry, 2010.

[9] Fernandez, I. Yos, S. Safitri, and Y. Sanjoko, "Kekerabatan Bahasa dan Budaya Muna-ButonWakatobi di Kawasan Kepulauan Lepas Pantai Provinsi Sulawesi Tenggara: Kajian Linguistik Historis Komparatif dan Etnolinguistik," Yoyakarta, 2012.

[10] Sudaryanto, Metode dan aneka teknik analisis bahasa: Pengantar penelitian wahana kebudayaan secara linguistis. Yogyakarta: Duta Wacana University Press, 1993.

[11] Mahsun, Dialektologi Diakroni: Sebuah Pengantar. Yogyakarta: Gadjah Mada Univerity Press, 1995. 